\title{
Use of chloroplast microsatellites to differentiate oak populations
}

\author{
Marie-France DeguillouX ${ }^{\mathrm{a}, \mathrm{b}}$, Marie-Hélène PEMONGE ${ }^{\mathrm{a}}$, Rémy J. PetiT ${ }^{\mathrm{a} *}$ \\ a Institut National de la Recherche Agronomique, Station de Recherches Forestières, 69 route d'Arcachon, 33612 Cestas Cedex, France \\ b Centre Technique du Bois et de l'Ameublement, 10 avenue de St-Mandé, 75012 Paris, France
}

(Received 13 March 2003; accepted 22 January 2004)

\begin{abstract}
The possibility to use chloroplast microsatellites (cpSSRs) instead of restriction analysis of PCR-amplified DNA fragments to differentiate oak populations was tested in two economically important tree species: Quercus petraea and Quercus robur. The level and pattern of inter- and intraspecific cpDNA variation were studied over 48 French populations using a total of $24 \mathrm{cpSSR}$ loci. The same pattern of low intrapopulation diversity and high population differentiation was noted with both types of markers, since there was an almost total redundancy of haplotypes identified with both techniques. Overall, our results indicate that chloroplast microsatellites can be used for haplotype discrimination in many contexts including certification or traceability of oak material.
\end{abstract}

microsatellites / cpSSR / PCR-RFLP / haplotypic diversity / population genetics

Résumé - Utilisation des microsatellites chloroplastiques pour différencier des populations de chênes. Nous avons cherché à comparer l'efficacité de deux types de marqueurs chloroplastiques, les marqueurs microsatellites (cpSSR) et marqueurs PCR-RFLP (cpRFLP), à différencier des populations de chênes sessiles et pédonculés, deux espèces d'arbres forestiers économiquement importantes. Le niveau et la structuration de la diversité inter et intra-spécifique ont été mesurés au sein de 48 populations françaises au travers de l'analyse de 24 microsatellites chloroplastiques. Une faible diversité intra-population, ainsi qu'une forte différenciation des populations de chênes ont pu être mesurées à l'aide des deux types de marqueurs, du fait d'une redondance quasi-complète des haplotypes identifiés par les deux techniques. Nos résultats indiquent donc que les marqueurs microsatellites chloroplastiques peuvent être utilisés pour la distinction d'haplotypes et de populations de chênes dans le cadre de la certification ou de la traçabilité de matériel forestier (graines, plants, bois).

microsatellites / cpSSR / PCR-RFLP / diversité haplotypique / génétique des populations

\section{INTRODUCTION}

Microsatellites, i.e. tandem DNA repeats characterised by short ( $<6$ bp) motifs, have been identified in plant nuclear and mitochondrial genomes [26] as well as in the chloroplast genome, where mononucleotide A:T repeats are almost exclusively observed [29]. The relevance of assays based on nuclear microsatellites for genetic analysis is well established. The principle has been extended to the chloroplast genome in a variety of species $[18,22]$. The chloroplast genome is a useful source of markers for genetic studies of plants because of conserved gene order and general lack of heteroplasmy and recombination. Its generally uniparental mode of inheritance makes it a powerful tool to elucidate relative contributions of seed and pollen flow to the genetic structure of natural populations by comparison with nuclear markers. Whilst nuclear microsatellites are the marker system of choice for genetic diversity, genome mapping, DNA fingerprinting and parentage analysis, chloroplast microsatellites (cpSSRs) revealed to be of special value in studies of plant population geographic structure and differentiation $[2,7,20]$ and for paternity analysis in the specific case of conifers [30]. However, as for nuclear microsatellites, a high level of homoplasy (alleles identical in size but not necessarily identical by descent due to convergent mutations) is expected [11].

The variation of cpSSRs within and among populations has been studied in several forest tree species but so far mostly in conifers (e.g. [19, 27]) where cpDNA is paternally inherited. To date, these studies concerning conifers have revealed much higher levels of diversity than have those based on restriction enzyme studies of PCR-amplified cpDNA fragments (PCRRFLP). Few population genetic analyses of cpSSRs in angiosperm forest trees have been reported so far [1, 13, 24] although the situation is likely to change rapidly. Here, we propose to evaluate the usefulness of cpSSRs markers for the detection of cpDNA polymorphisms in two economically important oak species: the sessile oak (Quercus petraea [Matt.] Liebl.) and the pedunculate oak (Quercus robur L.). The chloroplast genome has been shown to be maternally inherited in Q. robur [8]. A very detailed study of cpDNA variation based

\footnotetext{
* Corresponding author: petit@pierroton.inra.fr
} 
on PCR-RFLP has been conducted in European sessile and pedunculate oaks and in related species, with as many as 2613 forests (12 214 trees) typed by a consortium of 16 laboratories [15]. The molecular screening, based on restriction analysis of four PCR-amplified cpDNA fragments, permitted to determine $32 \mathrm{cpDNA}$ variants (cpRFLP variants), grouped in six maternal lineages whose distributions, together with available palynological information, were used to infer colonisation routes out of the glacial period refugia [16].

The use of cpSSRs instead of PCR-RFLP could be of particular interest in the case of these oaks species, some of which being of major economical importance. Indeed, new variants permitting to discriminate more precisely provenance regions could be used for certification of seedlots but also for the control of the geographic origin of oak wood, since retrieval and amplification of DNA from dry oak wood has been recently demonstrated $[4,10]$. Recently, the certification of timber from sustainably managed forests by international organisations (FSC-Forest Stewardship Council, PEFC-Pan European Forest Certification) led to develop chain of custody rules in the forest industry and trade to ensure an efficient and cost effective systems of tracing products back from the consumers to the woods. Rapid molecular analysis permitting to check the genetic conformity of woods with announced origins could become part of this tracing process. Since oak chloroplast DNA markers are strongly differentiated throughout the European continent as well as among forests, analysis of cpSSRs could come up to those expectations.

So far, sequences used to design primer pairs for amplification of cpSSRs have been deduced from database entries. In particular, the availability of a few complete chloroplast sequences from angiosperms and from one gymnosperm, along with that of numerous partial cpDNA sequences, was a prerequisite to design primers that amplify microsatellite regions. The high conservation of the chloroplast genome permitted the design of (a few) conserved primer pairs for the study of mononucleotide repeats variation in angiosperms [29]. Recently, we developed a set of cpSSRs primer pairs for oak species, from newly obtained Quercus cpDNA sequences [5]. Here we evaluate the usefulness of these two sets of cpSSRs loci to detect intraspecific variation in oaks. The level and pattern of inter- and intraspecific cpSSR variation is studied on 48 French populations of $Q$. robur and $Q$. petraea and is directly compared to that measured with PCR-RFLPs. We then compare the distribution of microsatellites sizes across 14 European oak haplotypes with the phylogeny deduced by PCR-RFLP studies [9]. We conclude by discussing the relative advantages of each type of marker.

\section{MATERIALS AND METHODS}

\subsection{Plant material}

A total of 48 French oak populations (comprising Quercus robur and/or Quercus petraea) were selected for cpSSR analysis. The populations were chosen among those included in a previous analysis of the phylogeographic structure of oaks throughout Europe that relied on PCR-RFLP [9]. Given the low intrapopulation cpDNA polymorphism found in oak populations, only two to three individuals were analysed per population for the present study. Fourteen of the European haplotypes defined by Dumolin-Lapègue et al. [9] were also assayed.

\subsection{DNA amplification}

A total of 17 loci (containing seven to 12 mononucleotide repeats), described in Deguilloux et al. [5] and selected from three oak chloroplast sequences (the intergenic regions $\operatorname{trn} \mathrm{D}-\operatorname{trn} \mathrm{T}$ and $\operatorname{trn} \mathrm{C}$ - $t r n \mathrm{D}$ and the intron of $t r n \mathrm{~K})$, as well as a set of seven additional angiosperm conserved primer pairs ("ccmp2 to 7" and "ccmp10") designed by Weising and Gardner [29] were analysed. All amplifications were performed according to Deguilloux et al. [5] and microsatellite analyses were carried out using the Li-Cor model 4000L automatic DNA sequencer.

\subsection{Genetic diversity}

Genetic differentiation was estimated as described in Pons and Petit [17] but modified for microsatellites. In order to take into account similarities between haplotypes, the measure $R_{\mathrm{ST}}$ was used, which is equal to $N_{\mathrm{ST}}$ except that the distance between two haplotypes is the sum (across all loci) of squared difference in the number of repeats (following Slatkin [25]). The program used to derive $G_{\mathrm{ST}}$ and $R_{\mathrm{ST}}$ (called CPSSR) is available at http://www.pierroton.inra.fr/genetics/labo/ Software. $R_{\mathrm{ST}}$ was compared with $G_{\mathrm{ST}}$ using 500 permutations of haplotype identity (as in [3]).

\subsection{Phylogenetic analyses}

A neighbour-joining tree was constructed with cpSSRs data set, using PHYLIP Version 3.5c [12].

\section{RESULTS}

\subsection{Microsatellites targeting}

All cpSSR motifs analysed are located in non-coding sequences, except $\mu \mathrm{kk} 2$, which is located in the mat $\mathrm{K}$ gene (within the trnK intron). The targeted microsatellites include repetitions of seven to 12 mononucleotides. Only one of them is a $(\mathrm{G}: \mathrm{C})_{\mathrm{n}}$ motif, all others being $(\mathrm{A}: \mathrm{T})_{\mathrm{n}}$ motifs [5].

\subsection{Intraspecific variation in oaks}

Variation at 24 cpSSRs loci was tested on 116 individuals from 48 French oak populations and on 28 individuals representing 14 PCR-RFLP haplotypes (two individuals per haplotype). A total of 10 loci (42\%) were polymorphic at the intraspecific level (Tab. I): $\mu \mathrm{dt} 1, \mu \mathrm{dt} 3$ and $\mu \mathrm{dt} 4$ located in the intergenic region trnD-trn $\mathrm{T}, \mu \mathrm{cd} 44$ and $\mu \mathrm{cd} 45$ located in the intergenic region $\operatorname{trn} \mathrm{C}-t r n \mathrm{D}, \mu \mathrm{kk} 3$ and $\mu \mathrm{kk} 4$ located in the intron of $t r n \mathrm{~K}$, and ccmp2, ccmp6 and ccmp10 designed by Weising and Gardner [29]. Between two and five size variants could be found at those loci. Considering only the 17 new motifs defined by our strategy (i.e. a selection of all motifs of at least seven repetitions), there was a positive relationship between the variability of the loci (number of alleles per locus) and the maximum number of repetitions for that motif $\left(r^{2}=0.67\right)$.

No distinction was observed between $Q$. robur and $Q$. petraea who are sharing the same cpSSRs haplotypes. The four cpSSR haplotypes found in France had very similar distribution 
Table I. CpSSRs variation size across oaks cpRFLP haplotypes. Number gives the repeat number found in each cpSSR, except * where number gives the size variation (sequences not known).

\begin{tabular}{|c|c|c|c|c|c|c|c|c|c|c|c|c|}
\hline Lineage & $\begin{array}{l}\text { cpRFLP Haplotype } \\
\text { designation }\end{array}$ & $\begin{array}{c}\text { cpSSR Haplotype } \\
\text { designation }\end{array}$ & $\begin{array}{l}\mu \mathrm{dt} 1 \\
(\mathrm{~A}) \mathrm{n}\end{array}$ & $\begin{array}{l}\mu \mathrm{dt} 3 \\
(\mathrm{~A}) \mathrm{n}\end{array}$ & $\begin{array}{l}\mu \mathrm{dt} 4 \\
(\mathrm{~A}) \mathrm{n}\end{array}$ & $\underset{*}{\mathrm{ccmp} 2}$ & $\underset{*}{\operatorname{ccmp6}}$ & $\underset{*}{\operatorname{ccmp} 10}$ & $\begin{array}{l}\mu \mathrm{cd} 44 \\
(\mathrm{~T}) \mathrm{n}\end{array}$ & $\begin{array}{l}\mu \mathrm{cd} 45 \\
\text { (A)n }\end{array}$ & $\begin{array}{l}\mu \mathrm{kk} 3 \\
(\mathrm{~T}) \mathrm{n}\end{array}$ & $\begin{array}{l}\mu \mathrm{kk} 4 \\
(\mathrm{~T}) \mathrm{n}\end{array}$ \\
\hline $\mathrm{A}$ & A1 & A & 9 & 11 & 10 & 2 & 2 & 2 & 11 & 9 & 10 & 9 \\
\hline A & A2 & B & 10 & 11 & 10 & 2 & 2 & 2 & 11 & 9 & 10 & 9 \\
\hline A & $\mathrm{A} 3$ & $\mathrm{C}$ & 10 & 12 & 10 & 2 & 2 & 2 & 11 & 9 & 10 & 9 \\
\hline A & A4 & B & 10 & 11 & 10 & 2 & 2 & 2 & 11 & 9 & 10 & 9 \\
\hline B & B1 & $\mathrm{D}$ & 11 & 10 & 9 & 1 & 2 & 1 & 12 & 8 & 10 & 9 \\
\hline B & B2 & $\mathrm{D}$ & 11 & 10 & 9 & 1 & 2 & 1 & 12 & 8 & 10 & 9 \\
\hline B & B3 & $\mathrm{E}$ & 12 & 10 & 9 & 1 & 2 & 1 & 12 & 8 & 10 & 9 \\
\hline $\mathrm{C}$ & B4 & $\mathrm{F}$ & 10 & 9 & 9 & 2 & 1 & 2 & 11 & 9 & 10 & 9 \\
\hline $\mathrm{C}$ & $\mathrm{C} 1$ & $\mathrm{G}$ & 10 & 10 & 11 & 2 & 2 & 2 & 12 & 9 & 10 & 8 \\
\hline $\mathrm{D}$ & D1 & K & 10 & 10 & 9 & 2 & 2 & 2 & 11 & 9 & 10 & 9 \\
\hline $\mathrm{E}$ & E1 & $\mathrm{H}$ & 10 & 8 & 9 & 2 & 2 & 2 & 12 & 9 & 11 & 9 \\
\hline E & E2 & I & 11 & 8 & 8 & 2 & 2 & 2 & 12 & 9 & 11 & 9 \\
\hline $\mathrm{E}$ & E3 & $\mathrm{J}$ & 11 & 8 & 8 & 2 & 2 & 2 & 11 & 9 & 11 & 9 \\
\hline E & $\mathrm{E} 4$ & I & 11 & 8 & 8 & 2 & 2 & 2 & 12 & 9 & 11 & 9 \\
\hline
\end{tabular}

compared to those identified by PCR-RFLP (Fig. 1). In fact, an exact correspondence was found between cpSSR haplotype $\mathbf{g}$ and cpRFLP haplotype $\mathbf{C 1}$, cpSSR haplotype $\mathbf{b}$ and cpRFLP haplotype A4, cpSSR haplotype d and cpRFLP haplotypes B1B2 and cpSSR haplotype e and cpRFLP haplotype B3 [9]. In particular, no haplotype detected by PCR-RFLP was polymorphic at any of these cpSSRs. As for PCR-RFLP haplotypes, most populations were fixed for one variant. Genetic differentiation $\left(R_{\mathrm{ST}}\right)$ was 0.72 , not significantly different from $G_{\mathrm{ST}}$ (0.75).

The analysis of cpSSR variation in the 30 individuals corresponding to 15 haplotypes defined by PCR-RFLP [9] allowed to differentiate $11 \mathrm{cpSSR}$ haplotypes, with the PCR-RFLP haplotypes A2 and A4, B1 and B2, E2 and E4 sharing the same cpSSRs combination (Tab. I). Again, no microsatellite could differentiate individuals sharing the same cpRFLP type. The microsatellite variants distinguish lineages already defined by PCR-RFLP. The neighbour-joining tree based on the cpSSR data, although less resolutive than that obtained with PCRRFLP markers, shows a clear separation of haplotypes corresponding to the previously defined lineages B and $\mathrm{E}$ from those belonging to other lineages (Fig. 2). The comparison of cpSSRs sizes across PCR-RFLP haplotypes indicates that phylogenetically distant haplotypes can share the same size cpSSR variant (defined as homoplasy). For example, the cpRFLP haplotypes C1, D1, B1, B2 and B3, which belong to different cpRFLP lineages, share the same length variant at the SSR locus $\mu \mathrm{dt} 3$.

\section{DISCUSSION}

Mononucleotide repeats turned out to be abundant in oak chloroplast sequences. Their presence was noted in all three oak sequences studied, with A:T repeats being almost exclusively observed, as found in the Nicotiana tabacum genome $(100 \%$ of loci with more than 10 repeats are A:T mononucleotides repeats [29]). We found a density of one (A:T $)_{10}$ every kilobase, i.e. more than the density found in tobacco (one $(\mathrm{A}: \mathrm{T})_{10}$ each $4 \mathrm{~kb}$ according to Provan et al. [21]). However, the sequences targeted by our study do not represent a random-sample of the cpDNA genome, as we preferentially targeted fragments that were shown to be particularly polymorphic in previous studies [9]. Moreover, those three sequences are known to exhibit cpSSRs in all completely sequenced cpDNA genome of angiosperms: Oryza, Zea, Arabidopsis, Nicotiana, Oenothera, Spinacia [22]. Furthermore, the three sequences studied were all located in the chloroplast Large Single Copy region that exhibits the highest frequency of microsatellites motifs [22]. Altogether, these results indicate that it should be possible to identify regions within the chloroplast genome harbouring microsatellite motifs at higher frequencies than expected from surveys of completely sequenced genomes.

We could demonstrate the association between the amount of cpSSR variation and the size of the poly $(\mathrm{A}: \mathrm{T})$ under study. In nuclear microsatellites, the variability of a locus has often been shown to be positively correlated with the number of uninterrupted repeats [23], but no relation had been identified so far using cpSSRs. In comparison to previous studies that analysed motifs of at least 10 repeats, we analysed all regions characterised by seven or more repeats. This allowed us to show that motifs shorter than 10 repeats can be polymorphic ( 80 and $83 \%$ of our cpSSR exhibiting at least 8 and 9 repeats turned out to be polymorphic). However, the study also confirms that the probability to find variation increases with the number of repeats.

An almost total redundancy of haplotypes defined using cpSSRs and PCR-RFLP was noted in our sample. Indeed, size variation was found among but not within haplotypes identified on the basis of restriction site data. The level of cpSSR diversity in France $\left(h_{\mathrm{T}}=0.65\right)$ was slightly lower than that obtained with PCR-RFLP $\left(h_{\mathrm{T}}=0.72,[15]\right)$. As in previous studies based on 


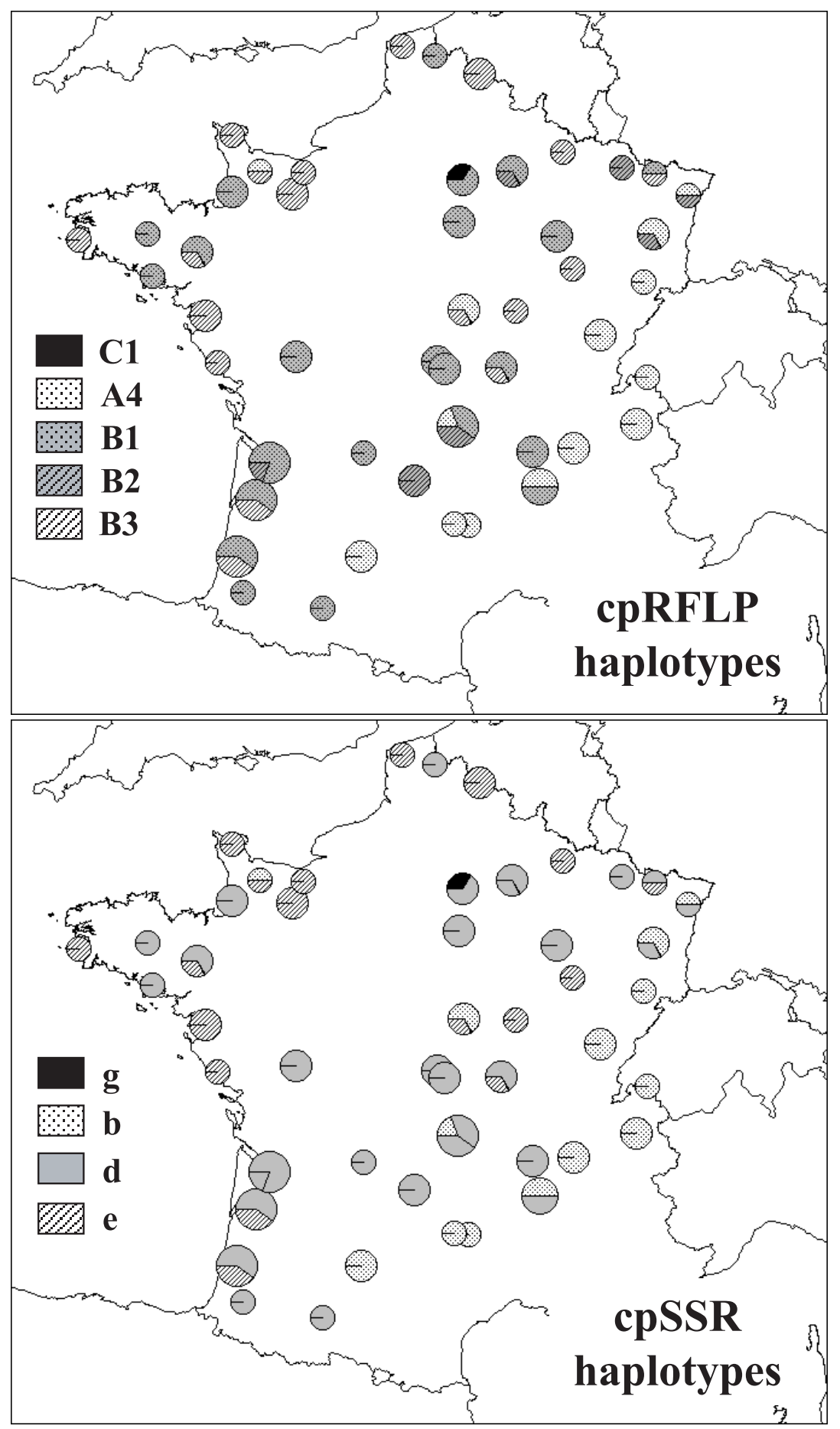

Figure 1. Map of cpRFLPs and cpSSRs haplotypes characterised in our French sample (cpRFLPs haplotypes according to Dumolin-Lapègue et al. [9], diameter of the circle proportional to individuals number).

PCR-RFLP, geographic structure was high and no distinction was obtained between $Q$. robur and $Q$. petraea, a consequence of introgression between these two species (e.g. [14]).
Higher levels of diversity may be detected by scoring many more cpSSRs, and especially longer, potentially more variable, motifs. Obtaining the complete Quercus cpDNA sequence 


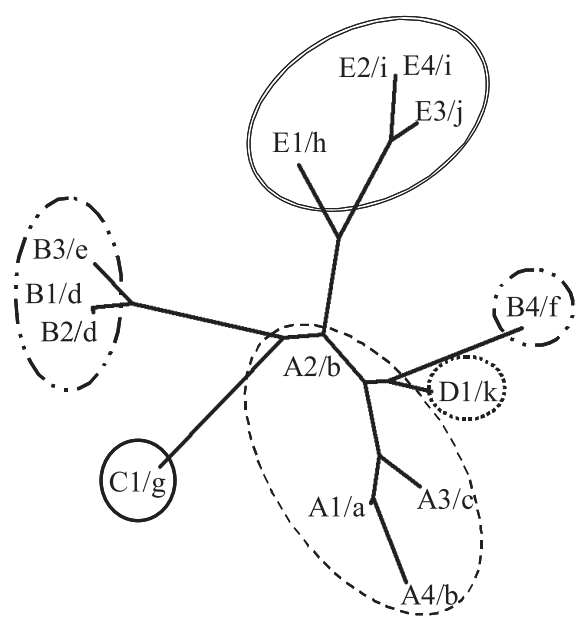

Figure 2. Neighbour-joining tree of the 11 oak cpSSR/cpRFLP haplotypes, constructed with cpSSRs data set in our European screening (each type of line drawing corresponds to a cpRFLPs lineage).

would therefore be especially valuable. Furthermore, the relationship of cpSSRs variability with the maximum number of repeats suggests that comparison of levels of diversity across species (e.g. conifers versus angiosperms) may be misleading, unless care is taken to use loci having similar sizes. This problem has been called the ascertainment bias in studies of nuclear SSRs, for orthologous loci [28].

The finding that recurrent and/or back mutations occur at these cpSSRs (generating homoplasy) was an expected result (see e.g. [7]), but which serves to illustrate their high mutation rate (lower than nuclear SSRs, but higher than elsewhere in the chloroplast genome [21]) and their potential to identify additional diversity. The simultaneous use of several chloroplast microsatellites along with the use of other types of mutations (such as those identified by PCR-RFLP) could help overcome these problems.

Finally, the numerous technical advantages of cpSSRs make them attractive genetic markers for traceability purposes. Indeed, their amplification is straightforward and several loci can be multiplexed, increasing the throughput of the cpDNA typing. In particular, the analysis of cpSSRs on DNA isolated from dry oak wood should be particularly promising. In this case, new primers should be designed to amplify short fragments, that include the microsatellites motifs, on degraded DNA isolated from oak wood, as shown previously [4]. However, this will depend on the nature of the regions immediately flanking the microsatellite, as they may in some cases be inappropriate for primer design. In the case of too modified and degraded DNA, single nucleotide polymorphisms may be preferred, as mononucleotide repeats may be prone to amplification errors by slippage. Despite these limitations, cpSSRs should prove valuable in the context of forest ecocertification and conservation and could be helpful to track illegally logged timber or mislabelled wood, as in the case of wood used by the French barrel industry [6].
Acknowledgements: This study has been carried out with financial support from the CTBA (Centre Technique du bois et de l'Ameublement), the Fédération Française de Tonnellerie, the Ministère de l'Agriculture et de la Pêche (DERF), the Ministère de la Recherche, the Commission of the European Communities (FEOGA in PDZR Aquitaine programme and FOSSILVA project (EVK2-1999-00015P) and INRA (Institut National de la Recherche Agronomique).

\section{REFERENCES}

[1] Besnard G., Khadari B., Baradat P., Berville A., Olea europaea (Oleaceae) phylogeography based on chloroplast DNA polymorphism, Theor. Appl. Genet. 104 (2002) 1353-1361.

[2] Bryan G.J., McNicoll J., Ramsay G., Meyer R.C., Jong W.S., Polymorphic simple sequence repeat markers in the chloroplast genomes of Solanaceous plants, Theor. Appl. Genet. 99 (1999) 859867.

[3] Burban C., Petit R.J., Carcreff E., Jactel H., Rangewide variation of the maritime pine bast scale Matsucoccus feytaudi Duc. (Homeroptera: Matsucoccidae) in relation to the genetic structure of its host, Mol. Ecol. 8 (1999) 1593-1602.

[4] Deguilloux M.F., Pemonge M.H., Petit R.J., Novel perspectives in wood certification and forensics: dry wood as a source of DNA Proc. R. Soc. London B: Biol. Sci. 269:1495 (2002) 1039-1046.

[5] Deguilloux M.F., Dumolin-Lapègue S., Gielly L., Grivet D., Petit R.J., A set of primers for the amplification of chloroplast microsatellites in Quercus, Mol. Ecol. Notes 3 (2003) 24-27.

[6] Deguilloux M.F., Pemonge M.H., Petit R.J., DNA-based control of oak wood origin in the context of the cooperage industry, Ann. For. Sci. 61 (2004) 97-104.

[7] Doyle J.J., Morgante M., Tingey S.V., Powell W., Size homoplasy in chloroplast microsatellites of wild perennial relatives of soybean (Glycine subgenus Glycine), Mol. Biol. Evol. 15 (1998) 215-218.

[8] Dumolin-Lapègue S., Demesure B., Petit R.J., Inheritance of chloroplast and mitochondrial genomes in pedunculate oaks investigated with an efficient PCR method, Theor. Appl. Genet. 91 (1995) 1253-1256.

[9] Dumolin-Lapègue S., Demesure B., Fineshi S., Le Corre V., Peti R.J., Phylogeographic structure of white oaks throughout the European continent, Genetics 146 (1997) 1475-1487.

[10] Dumolin-Lapègue S., Petit R.J., Gielly L., Taberlet P., Amplification of DNA from ancient and modern oak wood, Mol. Ecol. 8 (1999) 2137-2140.

[11] Estoup A., Jarne P., Cornuet J.M., Homoplasy and mutation model at microsatellite loci and their consequences for population genetics analysis, Mol. Ecol. 11 (2002) 1591-1604.

[12] Felsenstein J., PHYLIP (Phylogeny Inference Package) version 3.5c. Department of Genetics, University of Washington, Seattle, 1993.

[13] Palmé A.E., Vendramin G.G., Chloroplast DNA variation, postglacial recolonization and hybridization in hazel, Corylus avellana, Mol. Ecol. 11 (2002) 1769-1780.

[14] Petit R.J., Pineau E., Demesure B., Bacilieri R., Ducousso A., Kremer A., Chloroplast DNA footprints of postglacial recolonization by oaks, Proc. Natl. Acad. Sci. USA 94 (1997) 9996-10001.

[15] Petit R.J., Csaikl U.M., Bordács S. et al., Chloroplast DNA variation in European white oaks phylogeography and patterns of diversity based on data from over 2600 populations, For. Ecol. Manage. 156 (2002) 5-26.

[16] Petit R.J., Brewer S., Bordács S. et al., Identification of refugia and postglacial colonisation routes of European white oaks based on chloroplast DNA and fossil pollen evidence, For. Ecol. Manage. 156 (2002) 49-74.

[17] Pons O., Petit R.J., Estimation, variance and optimal sampling of gene diversity. I. Haploid locus, Theor. Appl. Genet. 90 (1995) $462-470$.

[18] Powell W., Morgante M., Andre C., McNicol J.W., Machray G.C., Doyle J.J., Tingey S.V., Rafalski J.A., Hypervariable chloroplast 
microsatellites provide a general source of polymorphic DNA markers for the chloroplast genome, Curr. Biol. 5 (1995) 1023-1029.

[19] Powell W., Morgante M., McDevitt R., Vendramin G.G., Rafalski J.A., Polymorphic simple sequence repeat regions in chloroplast genomes: application to the population genetics of pines, Proc. Natl. Acad. Sci. USA 92 (1995) 7759-7763.

[20] Provan J., Corbett G., McNicol J.W., Powell W., Chloroplast variability in wild and cultivated rice (Oryza spp.) revealed by polymorphic chloroplast single sequence repeats, Genome 40 (1997) 104110.

[21] Provan J., Soranzo N., Wilson N.J., Goldstein D.B., Powell W., A low mutation rate for chloroplast microsatellites, Genetics 153 (1999) 943-947.

[22] Provan J., Powell W., Hollingsworth P.M., Chloroplast microsatellites: new tools for studies in plant ecology and evolution. Trends Ecol. Evol. 16 (2001) 142-147.

[23] Saghai-Maroof M.A., Biyashev R.M., Yang G.P., Zhang Q., Allard R.W., Extraordinarily polymorphic microsatellite DNA in barley: species diversity, chromosomal locations, and population dynamics, Proc. Natl. Acad. Sci. USA 91 (1994) 5466-5470.

[24] Salvini D., Anzidei M., Fineschi S., Malvoti M.E., Taurchini D. Vendramin G.G., Low genetic differentiation among Italian populations of Populus tremula L. (Salicaceae) estimated using chloro- plast PCR-RFLP and microsatellite markers, For. Genet. 8 (2001) 81-87.

[25] Slatkin M., A measure of population subdivision based on microsatellite allele frequencies, Genetics 139 (1995) 457-462.

[26] Sperisen C., Büchler U., Gugerli F., Matyas G., Geburek T., Vendramin G.G., Tandem repeats in plant mitochondrial genomes: application to the analysis of population differentiation in the conifer Norway spruce. Mol. Ecol. 10 (2001) 257-263.

[27] Vendramin G.G., Anzidei M., Autino V.A., Madaghiele A., Morgante M., Sperisen C., Ziegenhagen B., Chloroplast microsatellites reveal high level of genetic diversity in conifers: a new tool for biodiversity analysis in forest ecosystems, Acta Hortic. 457 (1998) 395401.

[28] Webster T., Smith N.G.C., Ellegren H., Microsatellites evolution inferred from human-chimpanzee genomic sequence alignments, Proc. Natl. Acad. Sci. USA 99 (2002) 8748-8753.

[29] Weising K., Gardner R.G., A set of conserved PCR primers for the analysis of single sequence repeat polymorphisms in chloroplast genomes of dicotyledonous angiosperms, Genome 42 (1999) 9-19.

[30] Ziegenhagen B., Scholz F., Madaghiele A., Vendramin G.G., Chloroplast microsatellites as markers for paternity analysis in Abies alba, Can. J. For. Res. 28 (1998) 317-321. 